\title{
Determinan dan Efek Pengungkapan Corporate Social Responsibility pada Emiten Bursa Efek Indonesia Periode 2009-2014
}

\author{
Valentine Maria Olga Hadidjaja \\ Jurusan Akuntansi / Fakultas Bisnis dan Ekonomika \\ valentine.maria94@gmail.com
}

\begin{abstract}
Abstrak - Tujuan dari penelitian ini ialah untuk menguji apakah ukuran perusahaan berpengaruh terhadap pengungkapan CSR dan apakah pengungkapan CSR berpegaruh terhadap kinerja keuangan perusahaan. Kinerja keuangan perusahaan diproksikan menggunakan pertumbuhan pendapatan, ROA dan ROE. Penelitian ini dilakukan dengan menggunakan populasi perusahaan sektor keuangan yang terdaftar di BEI periode 2009-2014. Teknik pengambilan sampel yang digunakan ialah purposive judgement sampling.

Untuk data pengungkapan CSR, penelitian ini menggunakan indikator GRI serta metode content analysis. Pengukuran informasi CSR dilakukan menggunakan dummy variable. Bagi perusahaan yang mengungkapkan informasi yang terdapat pada indicator GRI maka akan diberi nilai 1, sedangkan yang tidak maka akan diberi nilai 0 . Pengujian hipotesis dilakukan dengan menggunakan analisis regresi berganda. Hasil penelitian menunjukkan jika ukuran perusahaan berpengaruh signifikan positif terhadap pengungkapan CSR. Sedangkan, pengungkapan CSR tidak ditemukan ada pengaruh terhadap kinerja keuangan perusahaan.
\end{abstract}

Kata kunci : pengungkapan CSR, ukuran perusahaan, kinerja keuangan, sektor keuangan

Abstract - The aim of this study was to examine the effect of company size on disclosure of CSR and the influence of CSR disclosure on the financial performance of the company. The company's financial performance is proxied using revenue growth, ROA and ROE. This study was conducted using a population of financial sector companies listed on the Stock Exchange 2009-2014. The sampling technique used was purposive judgment sampling.

For CSR disclosure of data, this study used the GRI indicators and methods of content analysis. CSR information measurement performed using dummy variables. For companies that disclose information contained in GRI indicators will be given a value of 1 , whereas it will be rated 0 . Hypothesis testing is done by using multiple regression analysis. The results show if the size company's positive significant effect on the disclosure of CSR. Meanwhile, CSR is not found no effect on the financial performance of the company.

Keywords: CSR Disclosure, company size, financial performance, financial sector 


\section{PENDAHULUAN}

Sektor keuangan merupakan salah satu sektor yang memegang peranan sangat signifikan dimana sektor keuangan bertugas untuk menyediakan para peminjam berbagai instrumen keuangan dengan kualitas tinggi dan risiko yang rendah. Oleh karena itu, sektor keuangan dapat dikatakan sebagai lokomotif bagi pertumbuhan sektor riil melalui akumulasi capital dan inovasi teknologi (Inggrid, 2006). Dalam benak kita, tentu masih jelas teringat bagaimana terjadinya krisis keuangan pada tahun 1998. Pemerintah Indonesia saat itu berencana melakukan pengetatan likuiditas untuk mengatasi masalah tersebut. Namun, ternyata usaha tersebut malah menimbulkan krisis kepercayaan masyarakat terhadap perbankan. Akibatnya, banyak masyarakat yang mengambil dananya secara besar-besaran (bank run) sehingga sejumlah bank mengalami saldo negatif (Unit Khusus Museum Bank Indonesia).

Krisis kepercayaan tersebut turut mengindikasikan jika reputasi perusahaan sektor keuangan juga mengalami krisis. Padahal, reputasi sangat penting bagi perusahaan sektor keuangan terutama bank guna menerima kepercayaan dari pelanggan dan stakeholder (Tran, 2014). Oleh karena itu, setiap perusahaan ada baiknya bila tidak hanya berfokus pada keuntungan saja tetapi juga tanggung jawab sosial. Hal itu dikarenakan setiap perusahaan akan menghadapi berbagai tantangan berkelanjutan dalam lingkungan yang kompetitif guna mencapai pertumbuhan jangka panjang (Farooque et al, 2009). Perusahaan harus mampu menyeimbangkan tata kelola perusahaan yang menyejahterakan masyarakat serta menjamin kelestarian lingkungan hidup seperti praktik tanggung jawab sosial, sehingga mampu eksisten dalam jangka panjang (Leki dan Christiawan, 2013). Tanggung jawab sosial atau yang lebih dikenal dengan corporate social responsibility (CSR) sangat erat hubungannya dengan pembangunan berkelanjutan (Rachman et al, 2011).

Terkait inisiatif penerapan CSR ini pemerintah Indonesia telah turut memberikan perhatiannya. Hal itu dapat dilihat melalui Undang-Undang mengenai Perseroan Terbatas yaitu UU No 40 Tahun 2007, PP No 47 Tahun 2012 dan sebagainya. Selain mewajibkan aktivitas CSR, berbagai event juga telah dilaksanakan 
guna mendukung penerapan CSR oleh perusahaan di Indonesia. Namun, kepedulian perusahaan di Indonesia terhadap fungsi tanggung jawab sosial masih tergolong parah karena kurang dari 50\% yang menerapkan program CSR terutama di bidang lingkungan (Antaranews, 2007). Beberapa penelitian telah dilakukan untuk menguji faktor apa yang mempengaruhi perusahaan mengungkapkan aktivitas CSR, dimana salah satunya ialah ukuran perusahaan. Perusahaan yang lebih besar akan cenderung untuk melakukan kegiatan operasinya sesuai dengan batasan, nilai dan aturan yang berlaku di masyarakat (Harvey, 2014). Organisasi besar dinilai lebih banyak melakukan kegiatan dan memiliki dampak yang lebih besar sehingga tekanan yang dihadapi lebih besar untuk mengungkapkan kegiatan sosial mereka (Cowen et al, 1987 dalam Mardikanto 2014).

Namun, penelitian yang dilakukan oleh Ehijie (2013) menunjukkan hal sebaliknya. Menggunakan perusahaan di Nigeria, hasil penelitiannya menunjukkan jika ukuran perusahaan tidak memiliki pengaruh terhadap level CSR yang diungkapkan oleh perusahaan. Selain ukuran perusahaan, pertimbangan manfaat apa yang akan didapat perusahaan jika terlibat dalam aktivitas CSR juga turut menjadi penyebab kepedulian perusahaan terhadap CSR masih rendah. Berdasarkan Waddock (1997), perusahaan yang terlibat dalam aktivitas CSR cenderung memiliki biaya yang tidak perlu. Biaya tersebut menyebabkan laba perusahaan menurun dan mengurangi pendapatan pemegang saham (Cheung dan Mak, 2010). Beberapa penelitian juga telah dilakukan untuk menguji pengaruh CSR terhadap kinerja keuangan perusahaan, misalnya saja penelitian yang dilakukan oleh Fauzi et al (2007) dan Yaparto et al (2013). Penelitian tersebut dilakukan dengan menggunakan perusahaan Indonesia. Namun hasil penelitian menunjukkan jika CSR tidak memiliki pengaruh terhadap kinerja keuangan.

Hasil penelitian tersebut nampaknya bertentangan dengan yang dilakukan oleh Choi et al (2010). Hasil penelitiannya menunjukkan ada pengaruh positif antara CSR dan kinerja keuangan perusahaan dengan menggunakan sampel perusahaan Korea. Mendukung penelitian Choi et al, penelitian yang dilakukan oleh Waddock dan Graves (1997) menunjukkan jika CSR terbukti signifikan positif terhadap ROA. 
Hal serupa ditemukan pada penelitian yang dilakukan Bayoud et al (2012), Khaveh et al (2012) menemukan pengungkapan CSR memiliki pengaruh yang signifikan dan positif terhadap kinerja keuangan perusahaan. Kesimpangsiuran hasil penelitian yang telah ada tersebut, membuat peneliti tertarik untuk melakukan penelitian mengenai faktor apa yang mempengaruhi perusahaan untuk mengungkapkan aktivitas CSR dan efek apa yang didapat perusahaan setelah mengungkapkan aktivitas CSRnya.

\section{METODE PENELITIAN}

Penelitian ini dilakukan menggunakan populasi seluruh perusahaan sektor keuangan yang terdaftar di BEI periode 2009-2014. Untuk pengambilan sampel, peneliti menggunakan teknik purposive judgement sampling. Hal itu dilakukan agar sampel yang digunakan benar-benar sesuai dengan tujuan penelitian. Tingkat keterlibatan peneliti dalam penelitian ini adalah minimal. Peneliti tidak melakukan intervensi terhadap objek penelitian. Data yang diambil merupakan data sesungguhnya terjadi, yang diambil tanpa melakukan manipulasi terhadap variabelvariabel yang ada. Sumber data yang digunakan ialah data sekunder. Data-data tersebut diperoleh dari website BEI, www.idx.co.id yang terdiri dari annual report dan laporan keuangan perusahaan, website resmi perusahaan yang berupa laporan keuangan, laporan tahunan dan sustainability report perusahaan, Indonesian Capital Market Directory (ICMD) serta Factbook Indonesia.

Skala pengukuran yang digunakan peneliti ialah skala rasio dan ordinal. Skala rasio adalah skala dimana angka mempunyai makna yang sesungguhnya sehingga angka nol dalam skala ini diperlakukan sebagai dasar perhitungan dan pengukuran objek penelitian. Dalam penelitian ini yang menjadi skala rasio ialah pertumbuhan pendapatan, ROA, ROE, leverage ratio, dan ukuran perusahaan. Sedangkan untuk CSRDI menggunakan skala ordinal. Rancangan uji hipotesis yang dilakukan pertamatama ialah uji asumsi klasik. Setelah uji asumsi klasik terpenuhi, kemudian dilanjutkan dengan uji analisis regresi berganda.

Berikut ini adalah hipotesis yang diuji,

H1 : ukuran perusahaan berpengaruh positif terhadap pengungkapan CSR 
H2 : pengungkapan CSR berpengaruh positif terhadap pertumbuhan pendapatan

H3 : pengungkapan CSR berpengaruh positif terhadap ROA

H4 : pengungkapan CSR berpengaruh positif terhadap ROE

\section{HASIL DAN PEMBAHASAN}

Berikut ini adalah tampilan kriteria pengambilan sampel yang akan digunakan,

Tabel 1

Kriteria Pemilihan Sampel Hipotesis I dan II

\begin{tabular}{|l|c|c|c|c|}
\hline \multicolumn{1}{|c|}{ Keterangan } & $\mathbf{1}$ & $\mathbf{2 . 1}$ & $\mathbf{2 . 2}$ & $\mathbf{2 . 3}$ \\
\cline { 2 - 5 } & Jumlah & Jumlah & Jumlah & Jumlah \\
\hline Perusahaan sektor keuangan yang listing di BEI & $\mathbf{7 6}$ & $\mathbf{2 2 8}$ & $\mathbf{2 2 8}$ & $\mathbf{2 2 8}$ \\
\hline Perusahaan sektor keuangan yang delisting dari BEI & 1 & 3 & 3 & 3 \\
\hline Perusahaan yang tidak melaporkan aktivitas CSR & 11 & 33 & 33 & 33 \\
\hline $\begin{array}{l}\text { Perusahaan yang data keuangan atau laporan tahunan tidak } \\
\text { tersedia secara lengkap }\end{array}$ & 2 & 6 & 6 & 6 \\
\hline Perusahaan yang memiliki ekuitas negatif & 3 & 9 & 9 & 9 \\
\hline Perusahaan yang berpindah sektor usaha & 1 & 3 & 3 & 3 \\
\hline Perusahaan yang bersifat outlier & $\mathbf{2}$ & $\mathbf{1 0}$ & $\mathbf{1 4}$ & $\mathbf{1 4}$ \\
\hline Total sampel final & $\mathbf{5 6}$ & $\mathbf{1 6 4}$ & $\mathbf{1 6 0}$ & $\mathbf{1 6 0}$ \\
\hline
\end{tabular}

*diolah penulis (2015)

Tabel 2

Kriteria Pemilihan Sampel Hipotesis III dan IV

\begin{tabular}{|l|c|c|c|c|c|c|}
\hline \multicolumn{1}{|c|}{ Keterangan } & $\mathbf{3 . 1}$ & $\mathbf{3 . 2}$ & $\mathbf{3 . 3}$ & $\mathbf{4 . 1}$ & $\mathbf{4 . 2}$ & $\mathbf{4 . 3}$ \\
\cline { 2 - 7 } & Jumlah & Jumlah & Jumlah & Jumlah & Jumlah & Jumlah \\
\hline Perusahaan sektor keuangan yang listing di BEI & $\mathbf{2 2 8}$ & $\mathbf{2 2 8}$ & $\mathbf{2 2 8}$ & $\mathbf{2 2 8}$ & $\mathbf{2 2 8}$ & $\mathbf{2 2 8}$ \\
\hline $\begin{array}{l}\text { Perusahaan sektor keuangan yang delisting dari } \\
\text { BEI }\end{array}$ & 3 & 3 & 3 & 3 & 3 & 3 \\
\hline $\begin{array}{l}\text { Perusahaan yang tidak melaporkan aktivitas } \\
\text { CSR }\end{array}$ & 33 & 33 & 33 & 33 & 33 & 33 \\
\hline $\begin{array}{l}\text { Perusahaan yang data keuangan atau laporan } \\
\text { tahunan tidak tersedia secara lengkap }\end{array}$ & 6 & 6 & 6 & 6 & 6 & 6 \\
\hline Perusahaan yang memiliki ekuitas negatif & 9 & 9 & 9 & 9 & 9 & 9 \\
\hline Perusahaan yang berpindah sektor usaha & 3 & 3 & 3 & 3 & 3 & 3 \\
\hline Perusahaan yang bersifat outlier & $\mathbf{1 2}$ & $\mathbf{9}$ & $\mathbf{1 2}$ & $\mathbf{7}$ & $\mathbf{8}$ & $\mathbf{7}$ \\
\hline \multicolumn{1}{|c|}{ Total sampel final } & $\mathbf{1 6 2}$ & $\mathbf{1 6 5}$ & $\mathbf{1 6 2}$ & $\mathbf{1 6 7}$ & $\mathbf{1 6 6}$ & $\mathbf{1 6 7}$ \\
\hline
\end{tabular}

* diolah penulis (2015) 
Setelah menentukan sampel yang digunakan kemudian penelitian dilanjutkan dengan uji asumsi klasik. Uji asumsi klasik ini terdiri dari uji normalitas, autokorelasi, heterokedastisitas, dan multikolinieritas. Uji ini dilakukan untuk masing-masing hipotesis. Untuk uji normalitas metode yang digunakan ialah one kolmogorov smirnov, uji autokorelasi menggunakan durbin watson, uji heterokedastisitas menggunakan spearman rho dan uji multikolinieritas menggunakan nilai tollerance dan VIF. Penelitian kemudian dilanjutkan dengan analisis regresi berganda. Berikut adalah rangkuman hasil uji yang telah dilakukan,

Tabel 3

Hasil Uji F

\begin{tabular}{|c|c|c|c|c|}
\hline Hipotesis & Model Pengujian & F Hitung & Sig. & Keterangan \\
\hline I & & 18.773 & 0.000 & Berpengaruh \\
\hline II & Model 1 & 0.152 & 0.928 & Tidak berpengaruh \\
\hline & Model 2 & 0.320 & 0.811 & Tidak berpengaruh \\
\hline III & Model 3 & 0.235 & 0.872 & Tidak berpengaruh \\
\hline & Model 1 & 15.512 & 0.000 & Berpengaruh \\
\hline & Model 3 & 18.293 & 0.000 & Berpengaruh \\
\hline IV & Model 1 & 6.505 & 0.000 & Berpengaruh \\
\hline & Model 2 & 4.325 & 0.006 & Berpengaruh \\
\hline & Model 3 & 2.091 & 0.103 & Tidak Berpengaruh \\
\hline
\end{tabular}

Tabel 4

Hasil Uji t

\begin{tabular}{|c|c|c|c|c|c|}
\hline Hipotesis & Model Pengujian & Variabel & Koefisien & T hitung & Sig. \\
\hline I & & Konstanta & -0.070 & -3.227 & 0.002 \\
\hline & & Firm Size & 0.006 & 3.854 & 0.000 \\
\hline & & Debt to Equity & 0.001 & 0.999 & 0.323 \\
\hline II & Model 1 & Konstanta & 0.111 & 0.824 & 0.411 \\
\hline & & CSRDI & -0.110 & -0.633 & 0.528 \\
\hline & & Debt to Equity & -0.002 & -0.349 & 0.728 \\
\hline
\end{tabular}




\begin{tabular}{|c|c|c|c|c|c|}
\hline & & Firm Size & 0.005 & 0.493 & 0.623 \\
\hline & Model 2 & Konstanta & 0.252 & 2.457 & 0.015 \\
\hline & & CSRDI & -0.026 & -0.228 & 0.820 \\
\hline & & Debt to Equity & $-4.847 \mathrm{E}-5$ & 0.014 & 0.989 \\
\hline & & Firm Size & -0.005 & -0.653 & 0.515 \\
\hline & Model 3 & Konstanta & 0.202 & 1.833 & 0.069 \\
\hline & & CSRDI & 0.010 & 0.078 & 0.938 \\
\hline & & Debt to Equity & -0.003 & -0.690 & 0.491 \\
\hline & & Firm Size & -0.001 & -0.110 & 0.913 \\
\hline \multirow[t]{12}{*}{ III } & Model 1 & Konstanta & 0.067 & 4.160 & 0.000 \\
\hline & & CSRDI & -0.010 & -0.532 & 0.595 \\
\hline & & Debt to Equity & -0.003 & -5.271 & 0.000 \\
\hline & & Firm Size & -0.001 & -1.079 & 0.282 \\
\hline & Model 2 & Konstanta & 0.076 & 4.597 & 0.000 \\
\hline & & CSRDI & -0.015 & -0.828 & 0.409 \\
\hline & & Debt to Equity & -0.003 & -5.489 & 0.000 \\
\hline & & Firm Size & -0.002 & -1.318 & 0.189 \\
\hline & Model 3 & Konstanta & 0.089 & 5.524 & 0.000 \\
\hline & & CSRDI & -0.014 & -0.754 & 0.452 \\
\hline & & Debt to Equity & -0.003 & -4.836 & 0.000 \\
\hline & & Firm Size & -0.003 & -2.275 & 0.024 \\
\hline \multirow[t]{12}{*}{ IV } & Model 1 & Konstanta & -0.033 & -0.742 & 0.459 \\
\hline & & CSRDI & -0.004 & -0.078 & 0.938 \\
\hline & & Debt to Equity & 0.001 & 0.383 & 0.702 \\
\hline & & Firm Size & 0.010 & 3.319 & 0.001 \\
\hline & Model 2 & Konstanta & 0.007 & 0.158 & 0.875 \\
\hline & & CSRDI & 0.003 & 0.053 & 0.958 \\
\hline & & Debt to Equity & $-5.486 \mathrm{E}-5$ & -0.038 & 0.970 \\
\hline & & Firm Size & 0.008 & 2.792 & 0.006 \\
\hline & Model 3 & Konstanta & 0.024 & 0.554 & 0.581 \\
\hline & & CSRDI & -0.017 & -0.352 & 0.726 \\
\hline & & Debt to Equity & -0.001 & -0.777 & 0.439 \\
\hline & & Firm Size & 0.007 & 2.306 & 0.022 \\
\hline
\end{tabular}

Dari tabel 4 tersebut dapat dilihat jika hanya pengujian hipotesis I yang diterima, sedangkan untuk hipotesis II, III, dan IV ditolak. Dikarenakan seluruh 
hipotesis yang menguji pengaruh pengungkapan aktivitas CSR terhadap kinerja keuangan perusahaan ditolak, maka peneliti melakukan analisis tambahan dengan membagi variabel kontrol yaitu ukuran perusahaan menjadi 2 kategori yaitu small size dan big size. Namun, ternyata setelah dilakukan analisis tambahan hasil pengujian tetap menunjukkan hasil yang sama.

Hasil pengujian terhadap hipotesis I ini mendukung penelitian yang telah dilakukan oleh Yao et al (2011), Uwuigbe (2011). Pengungkapan mengenai informasi aktivitas CSR perusahaan dijadikan sebagai wujud tanggung jawab dari perusahaan dan upaya perusahaan untuk bertindak ataupun melakukan kegiatan operasionalnya sesuai dengan batas, nilai dan aturan yang berlaku di masyarakat (Harvey, 2014). Disamping itu, hubungan positif tersebut juga dikarenakan stakeholder mengharapkan CSR yang lebih banyak dari perusahaan besar dibanding perusahaan kecil (Branco dan Rodrigues, 2008 dalam Vintila, 2013). Harapan stakeholder tersebut ditunjukkan dengan cara memberikan pengawasan yang lebih kepada perusahaan besar. Sebagai salah satu stakeholder, konsumen tidak segan-segan untuk memberikan reward bagi perusahaan yang memiliki kepedulian terhadap sosial dengan cara membayar lebih untuk produk perusahaan tersebut atau memberi punishment dengan cara menolak membeli produk (Chu dan Lin, 2012).

Adanya pengawasan tersebut membuat perusahaan besar menjadi lebih rentan dan menghadapi tekanan yang besar, sehingga mereka akan cenderung untuk mengungkapkan kegiatan sosial mereka (Cowen et al, 1987 dalam Haniffa dan Cooke, 2005). Berbeda dengan hipotesis I yang diterima, hasil pengujian hipotesis II, III dan IV menunjukkan jika pengungkapan CSR tidak memiliki pengaruh yang signifikan terhadap kinerja keuangan perusahaan. Hasil pengujian ini sesuai dengan penelitian yang telah dilakukan oleh Fauzi et al (2007), Najah dan Jarboui (2013), Santoso dan Feliana (2014). Secara umum, pemerintah Indonesia mewajibkan perusahaan untuk melaksanakan CSR, terutama Perseroan Terbatas. Kewajiban tersebut tercantum dalam sistem hukum nasional, yaitu UU No 40 Tahun 2007 dan peraturan lainnya. 
Akan tetapi, nyatanya kewajiban tersebut malah membuat perusahaan lebih termotivasi untuk melakukan CSR guna menghindari konflik dengan pemerintah dan masyarakat. Motivasi tersebut lebih besar jika dibandingkan dengan kemauan perusahaan untuk berfokus meningkatkan inovasi dan kualitas pada produk, maupun peduli terhadap pemeliharaan lingkungan, penghematan dan konservasi energi, yang menyebabkan CSR tidak berhubungan dengan penjualan (Leki dan Christiawan, 2013). Terlebih lagi, meskipun aktivitas CSR telah diwajibkan, pemerintah Indonesia masih belum memiliki panduan pelaksanaan CSR secara wajib dan sebagian besar perusahaan lebih memilih untuk melaksanakan program CSR berdasarkan kebijaksanaan mereka sendiri.

Ada sedikit yang menarik dari hasil penelitian ini, dimana variabel kontrol terbukti signifikan terhadap beberapa kinerja keuangan meskipun memiliki tanda yang berbeda. Dalam pengujian hipotesis III terlihat jika leverage yang berfungsi sebagai variabel kontrol terbukti signifikan negatif terhadap ROA dan hasil tersebut konsisten untuk semua model pengujian. Hasil ini sesuai dengan penelitian yang dilakukan oleh Kamatra dan Kartikaningdyah (2015) Mulyadi dan Anwar (2012) serta Yaparto et al (2013) yang menyatakan hal serupa, dimana leverage berpengaruh negatif terhadap ROA. Rasio leverage merupakan salah satu faktor yang dipertimbangkan untuk melakukan investasi. Oleh karena itu, semakin tinggi rasio leverage maka perusahaan akan menjaga image dan kinerja, guna menarik perhatian investor agar mau tertarik dan mempertimbangkan untuk melakukan investasi di perusahaan (Vidiananda dan Saraswati, 2013). Hubungan negatif tersebut juga dapat dikarenakan perusahaan yang memiliki kinerja keuangan yang baik akan cenderug untuk tidak melakukan pinjaman (Najah dan Jarboui, 2013).

Untuk pengujian hipotesis IV terlihat jika ukuran perusahaan yang berfungsi sebagai variabel kontrol terbukti signifikan positif terhadap ROE pada masingmasing model pengujian. Hasil tersebut sesuai dengan penelitian yang dilakukan oleh Santoso dan Feliana (2014), Yusoff et al (2013) dan Yaparto et al (2013) dimana ukuran perusahaan terbukti signifikan positif terhadap kinerja perusahaan. Menurut Brigham dan Houston (2001) dalam Leki dan Christiawan (2013), semakin besar 
ukuran peusahaan akan semakin mudah untuk mengakses pasar modal sehingga mudah untuk mendapatkan dana yang dibutuhkan dari kreditor. Dengan diperolehnya dana tersebut, maka perusahaan dapat membeli aset untuk memenuhi permintaan produk dan memperluas pangsa pasar. Dengan demikian kinerja perusahaan akan meningkat pula. Akan tetapi hasil ini bertentangan dengan penelitian Vidiananda dan Saraswati (2013), dimana mereka tidak menemukan adanya pengaruh ukuran perusahaan terhadap kinerja. Menurut mereka, naik atau turunnya kinerja perusahaan tidak didasari oleh ukuran perusahaan.

\section{KESIMPULAN DAN SARAN}

Berdasarkan penelitian dan analisis yang telah dilakukan maka dapat disimpulkan jika hanya hipotesis I saja yang diterima, yaitu ukuran perusahaan berpengaruh terhadap pengungkapan CSR. Sedangkan pengujian hipotesis lainnya yang menguji pengaruh pengungkapan CSR terhadap kinerja keuangan perusahaan terbukti ditolak. Hasil tersebut mengindikasikan jika pengungkapan CSR yang dilakukan perusahaan tidak memberikan pengaruh terhadap kinerja keuangan baik yang diukur menggunakan pertumbuhan pendapatan, ROA maupun ROE.

Dalam proses pengerjaan dan pengerjaan penelitian ini, penulis dihadapkan pada beberapa keterbatasan dan kendala. Beberapa keterbatasan dan kendala tersebut ialah, selang waktu yang digunakan untuk mengukur pengaruh CSR terhadap kinerja keuangan dalam penelitian hanya selama 2 tahun, sehingga tidak dapat menggambarkan bagaimana pengaruh antara CSR terhadap kinerja keuangan ataupun sebaliknya dalam jangka waktu yang lebih lama. Selain itu, variabel yang digunakan dalam penelitian sebagai variabel yang mempengaruhi pengungkapan CSR hanya terbatas pada ukuran perusahaan dan variabel yang digunakan dalam penelitian sebagai indikator kinerja keuangan hanya sebatas pertumbuhan pendapatan, ROA, ROE. Guna mengembangkan penelitian-penelitian sebelumnya, penelitian selanjutnya diharapkan dapat menggunakan selang waktu yang lebih lama dan menambah variabel-variabel lainnya untuk digunakan dalam penelitian. 


\section{DAFTAR PUSTAKA}

Antaranews. 2007. Kurang dari 50 Persen Perusahaan Laksanakan CSR. http://www.antaranews.com/berita/68802/kurang-dari-50-persen-perusahaanlaksanakan-csr (diakses tanggal 27 September 2015)

Afiff, Saffana dan Semuel PD Anantadjaya. 2013. CSR \& Performance: Any Evidence from Indonesian http://papers.ssrn.com/sol3/papers.cfm?abstract_id=2220242 (diunduh 30 September 2015)

Rogosic, Andrijana. 2014. Corporate social responsibility reporting of the banks in Bosnia and Herzegovina, Croatia and Montenegro. Theoretical and Applied Economic, Vol. 21 (9) : 71-82.

Bayoud, et al. 2012. An Empirical Study of The Relationship between Corporate Social Responsibility Disclosure and Organizational Performance: Evidence From Libya. International Journal of Management and Marketing Research, Vol. 5 (3).

Branco, M. C., dan L. L. Rodrigues. 2007. Positioning Stakeholder Theory within the Debate on Corporate Social Responsibility. Electronic Journal of Business Ethics and Organization Studies, Vol. 12 (1).

Chaudhury, et al. 2011. Practice of Corporate Social Responsibility (CSR) in Banking Sector in India: An Assessment. Research Journal of Economics, Business and CT, Vol. 4.

Chauhan, Swati dan Amit. 2014. A Relational Study of Firm's Characteristics and CSR Expenditure. Procedia Economics and Finance, Vol. 11: 23-32.

Cheung, P., dan Wilson Mak. 2010. The Relation Between Corporate Social Responsibility Disclosure and Financial Performance: Evidence From The Commercial Banking Industry. Working Paper. University Simon Fraser.

Choi et al. 2010. Corporate Social Responsibility and Corporate Financial Performance: Evidence from Korea. Australian Journal of Management, Vol.35 (4).

Chu, S. C. dan Jhih Syuan Lin. 2012. Do Chinese Consumers Care About Corporate Social Responsibility?. Asian Journal of Business Research, Vol. 2 (1).

Commision, European. 2011. Communication From The Commision To The European Parliament, The Council, The European Economic and Social Committee and The Committee of The Regions.

Ehijie, O. C. 2013. The Effect of Firm Size and Profitability on Corporate Social Disclosure: Empirical Evidence from Nigeria. Working Paper. University of Benin.

Egwuonwu, R. C. Iwu. 2010. Does Corporate Social Responsibility (CSR) Impact on Firm Performance? A Literature Evidence.

Farooque, et al. 2009. Impact of Corporate Social Responsibilitu on Consumer Loyalty and Purchase Intention. http://scholar.google.co.id/scholar_url?url=http://www.researchgate.net/profil e/Pierre_Valette- 
Florence/publication/258161479_The_Impact_of_Corporate_Social_Responsi bility_on_Organizational_Commitment_Exploring_Multiple_Mediation_Mec hanisms/links/00b7d52837ede311 cf000000.pdf\&hl=en\&sa $=\bar{X} \& s c i s i g=\bar{A} A G B$ fm0JflJAUMZKhMxoc5RDXqCqr7dXjg\&nossl=1\&oi=scholarr\&ved=0ahU KEwjT196YqtnJAhXHipQKHSrxAb4QgAMIGigBMAA (diunduh 15 Oktober 2015).

Fauzi et al. 2007. The Link between Corporate Social Performance and Financial Performance: Evidence from Indonesian Companies. Social and Environmental Accounting, Vol. 1 (1): 149-159.

Guthrie et al. 2007. Legitimacy Theory : A Story of Reporting Social and Environtmental Matters within the Australian Food and Beverage Industry. http://papers.ssrn.com/sol3/papers.cfm?abstract_id=1360518 (diunduh tanggal 20 November 2015)

Haniffa, Cooke. 2005. The Impact of Culture and Governance on Corporate Social Reporting. Journal of Accounting and Public Policy 24: 391-430.

Harvey, Will. 2014. Defining and connecting CSR, reputation, image, identity, brand, legitimacy, status and diversity. http://papers.ssrn.com/sol3/papers.cfm?abstract_id=2145134 (diunduh tanggal 20 November 2015)

Inggrid. 2006. Sektor Keuangan dan Pertumbuhan Ekonomi di Indonesia: Pendekatan Kausalitas dalam Multivariate Vector Error Correction Model (VECM). Jurnal Manajemen dan Kewirausahaan, Vol. 8 (1): 40-50.

Kamatra, N., dan Ely Kartikaningdyah. 2015. Effect Corporate Social Responsibility on Financial Performance. International Journal of Economics and Financial Issues.

Khaveh et al. 2012. Voluntary Sustainability Disclosure, Revenue, and Sahreholders Wealth-A Perspective from Singaporean Companies. Business Management Dynamics, Vol. 1 (9): 06-12.

Kotler, Philip dan Nancy Lee. 2005. Doing the Most Good for Your Company and Your Cause. New Jersey: John Wiley \& Sons, Inc.

Lawrence, Anne T., Weber, James. (2008). Business \& Society Stakeholders, Ethics, Public Policy. New York: Mc Graw Hill/Irwin.

Lawrence, Anne T., Weber, James. (2011). Business \& Society Stakeholders, Ethics, Public Policy. New York: Mc Graw Hill/Irwin.

Leki, R., dan Y. J. Christiawan. 2013. Pengaruh Corporate Social Responsibility (CSR) terhadap Penjualan dan Biaya Operasional Perusahaan di Bursa Efek Indonesia Tahun 2007-2011. Business Accounting Review, Vol. 1 (2).

Lindrawati, et al. 2008. Pengaruh Corporate Social Responsibility Terhadap Kinerja Keuangan Perusahaan yang Terdaftar sebagai 100 Best Corporate Citizens oleh KLD Research \& Analytics. Majalah Ekonomi Tahun XVIII No. 1.

Mardikanto, Totok. 2014. Corporate Social Responsibility (Tanggung Jawab Sosial Korporasi). Alfabeta: Bandung. 
Mulyadi, M. S., dan Y. Anwar. 2012. Impact of Corporate Social Responsibility Toward Firm Value and Profitability. The Business Review Cambridge, Vol. 19 (2).

Najah, A., dan A. Jarboui. 2013. The Social Disclosure Impact on Corporate Financial Performance: Case of Big French Companies. International Journal Management Business Research, 3 (4): 337-351.

Priyatno, Duwi. 2014. SPSS 22: Pengolahan Data Terpraktis. C.V ANDI OFFSET: Yogyakarta.

Rachman et al. 2011. Panduan Lengkap Perencanaan CSR. Penebar Swadaya: Jakarta.

Rogosic, A. 2014. Corporate Social Responsibility Reporting of the Banks in Bosnia and Herzegovina, Croatia and Montenegro. Theoritical and Applied Economics, Vol. 21 (9) : 71-82.

Semuel, H., dan Elianto Wijaya. 2008. Corporate Social Responsibility, Purchase Intention dan Corporate Image pada Restoran di Surabaya dari Perspektif Pelanggan. Jurnal Manajemen Pemasaran, Vol. 3 (1): 35-54.

Santoso, A. H., dan Yie Ke Feliana. 2014. The Association Between Corporate Social Responsibility And Corporate Financial Persormance. Social and Environmental Accounting, Vol. 8 (2): 82-103.

Sindonews. 2013. Ini 27 perusahaan peraih CSR Award Koran Sindo 2013. http://ekbis.sindonews.com/read/753575/34/ini-27-perusahaan-peraih-csraward-koran-sindo-2013-1372084074 (diakses 27 September 2015).

Surabayabisnis. 2014. Banyak Perusahaan Lakukan CSR Setelah Ada Masalah dengan Masyarakat. http://surabaya.bisnis.com/read/20141127/21/76387/banyak-perusahaanlakukan-csr-setelah-ada-masalah-dengan-warga (diakses 27 September 2015)

Titisari et al. 2010. Corporate Social Responsibility dan Kinerja Perusahaan. Simposium Nasional Akuntansi Purwokerto.

Tjia, Olivia dan Lulu Setiawati. 2012. Effect of CSR Disclosure to Value of the Firm: Study for Banking Industry in Indonesia. World Journal of Social Sciences, Vol. 2 (6) : 169-178.

Tran, Y. T. Hoang. 2014. CSR in Banking Sector A Literature Review and New Research Directions. International Journal of Economics, Commerce and Management, Vol. 2 (11).

Trang, H. N. T., dan L. S. Yekini. 2014. Investigating the Link between CSR and Financial Performance-Evidence from Vietnamese Listed Companies. British Journal of Arts and Social Sciences, Vol. 17 (1).

Tsoutsoura, M. 2004. Corporate Social Responsibility and Financial Performance. Working Paper. University of California at Berkeley.

Udayasankar, Krishna. 2007. Corporate Social Responsibility and Firm Size. Journal of Business Ethics, DOI 10.1007/s10551-007-9609-8.

Uwuigbe, Uwalomwa. 2011. An Empirical Investigation of the Asociation between Firm Characteristics and Corporate Social Disclosure in the Nigerian Financial Sector. Journal of Sustainable Development in Africa, Vol. 13 (1). 
Vidiananda, G., dan E.Saraswati. The Influence of Corporate Social Responsibility (CSR) on Company Financial Performance and Firm Value (An Empirical Study on the Manufacturing Companies Listed at Indonesia Stock Exchange (IDX) in 2011). https://www.google.co.id/url?sa $=t \& r c t=j \& q=\&$ esrc $=s \&$ source= $=$ web $\& c d=1 \& c$ $\mathrm{ad}=\mathrm{rja} \& u a c t=8 \& \mathrm{ved}=0$ ahUKEwi8ldGKpdnJAhWEnZQKHTqzC8gQFggcM AA\&url=http\%3A\%2F\%2Fjimfeb.ub.ac.id\%2Findex.php\%2Fjimfeb\%2Fartic le\%2FviewFile\%2F620\%2F563\&usg=AFQjCNGFkPWkEYsW2 X6pSVf7QZlkrwQWjw\&sig2=WyLofmQaV30QDRRcAOrSw\&bvm=bv.109910813,d.dGo (diunduh 25 November 2015).

Vintila, Georgeta. 2013. A Study of The Relationship between Corporate Social Responsibility-Financial Performance-Firm Size. Romanian Statistical Review Supplement, Vol. 61 (1): 62-67.

Viva. 2013. Plus Minus Program CSR di Indonesia. http://bisnis.news.viva.co.id/news/read/468051-plus-minus-program-csr-diindonesia (diakses tanggal 25 September 2015)

Waddock, S. A., dan Samuel B. Graves. 1997. The Corporate Social PerformanceFinancial Performance Link. Strategic Management Journal, Vol. 18 (4): 303319.

Wibisono, Yusuf. 2007. Membedah Konsep \& Aplikasi Corporate Social Responsibility. Fascho Publishing : Gresik.

Wibowo, A. Jatmiko. 2012. Interaction between Coprorate Social Responsibility Disclosure and Profitability of Indonesia Firms. International Annual Symposium on Sustainability Science and Management.

Woecharoen, Chutima. 2013. The Relationship between Corporate Social Responsibiity and Firm Performance from the Hotel Industry of Kho Samui Island Thailand. Global Accounting, Finane and Economic Conference.

Xie, Songjing. 2015. Corporate Social Responsibility and Firm Performance: OLS and Granger Causalit Analysis.

Yao et al. 2011. Determinant of Corporate Social Responsibility Disclosure by Chinese Firms. Discussion Paper. The University of Nottingham China Policy Institute.

Yaparto et al. 2013. Pengaruh Corporate Social Responsibility Terhadap Kinerja Keuangan pada Sektor Manufaktur yang Terdaftar di Bursa Efek Indonesia pada Periode 2010-2011. Calyptra Jurnal Ilmiah Mahasiswa Universitas Surabaya, Vol. 2 (1).

Yeon, A. L., dan Sabela. 2013. Mandatoy CSR Law in Indonesia : New Emerging Policy. Conference Paper. 7th Universiti Utara Malaysia International Legal Conference, Kuala Lumpur.

Yusoff et al. 2013. The Influence of CSR Disclosure Structure on Corporate Financial Performance: Evidence from Stakeholders Perspective. Procedia Economics and Finance, Vol. 7: 213-220. 